\title{
Water Pollution Laws in Sierra Leone-A Review with Examples from the UK and USA
}

\author{
Abubakarr S. Mansaray' ${ }^{1}$ Jason Aamodt², Bashiru M. Koroma ${ }^{3}$ \\ ${ }^{1}$ Oklahoma Water Resources Center, Department of Plant and Soil Science, Oklahoma State University, 139 Agricultural Hall, \\ Stillwater, Oklahoma, USA \\ ${ }^{2}$ Spears College of Business, Oklahoma State University, Stillwater, Oklahoma, USA \\ ${ }^{3}$ School of Postgraduate Studies, Njala University, Njala Campus, Freetown, Sierra Leone \\ Email: abu.mansaray@okstate.edu
}

How to cite this paper: Mansaray, A.S., Aamodt, J. and Koroma, B.M. (2018) Water Pollution Laws in Sierra Leone-A Review with Examples from the UK and USA. Natural Resources, 9, 361-388. https://doi.org/10.4236/nr.2018.911023

Received: November 6, 2018

Accepted: November 27, 2018

Published: November 30, 2018

Copyright (C) 2018 by authors and Scientific Research Publishing Inc. This work is licensed under the Creative Commons Attribution International License (CC BY 4.0).

http://creativecommons.org/licenses/by/4.0/

\begin{abstract}
In Sierra Leone, poor water quality is a major threat to public health and aquatic life. The main source of this problem appears to be poorly regulated waste disposal. Even though water pollution laws exist, their enforcement is challenged by many gaps and, seemingly, they focus on the quest to sustain natural resource exploitation. This work presents a case for strengthening such laws to promote public health, economic growth, and resource conservation. The article presents examples of problems that necessitated promulgation of water pollution laws in the US and the UK. Sierra Leone has been affected by similar problems such as public health, war efforts, and industrialization.
\end{abstract}

\section{Keywords}

Water Pollution, Permit, Public Health, Agriculture, Mining

\section{Introduction}

Before the 2000s, Sierra Leone did not prioritize environmental quality as an important pillar to sustainable development, albeit the need to do so in much the same way as the nation prioritized the social and economic considerations of policies and laws [1]. Reports have indicated, however, that poor environmental quality undermines achievement of economic gratification and societal satisfaction [2]. When public health is compromised by pollution, the country's productivity and competitiveness will take a downward trend [3]. This article presents a case for strengthening water pollution laws in Sierra Leone to enhance benign public health and aquatic life. 
Sierra Leone (Figure 1), a small West African country with a land area of about 72,000 sq. km (28,000 sq. mi) [4], has four main physical regions: the Freetown Peninsula, the coastal plains, the interior low lands, and the interior plateau. These create a landscape that drains 9 major river basins, all of which drain into the Atlantic Ocean in the west of the nation. The Freetown Peninsula is south of Freetown with hills and mountains ranging from 200 to $1000 \mathrm{~m}$ (656 to $3281 \mathrm{ft}$.) above the coast. The coastal plains stretch from the west to the southwest and are characterized by mangrove swamps and beautiful beaches along the shoreline of the Atlantic Ocean. The Interior Lowlands are mostly swamps making up about half of the country. The Interior Plateau region has elevations as high as $3000 \mathrm{~m}$ (9843 ft.) above sea level with a tropical rain forest in the northeast [5].

There are 5 administrative regions, the Northern, Northwestern, Southern, and Eastern Provinces, and the Western Area. These regions make up 16 administrative Districts and 190 administrative Chiefdoms. Each Chiefdom is made up of sections, towns, villages, and communities [6]. Sierra Leone also has political blocks demarcated by the National electoral commission. The 16 Districts make up 132 constituencies that elect representatives in the House of Parliament. In the Local Government, there are 446 wards that elect representatives in Council seats [6].

The nation has three main levels of governance-the Executive, Judiciary and Legislature. The President is the Head of State and heads the Executive branch of the presidential system of government. The second branch is the Judiciary, headed by the Chief Justice, and is responsible for enforcing the laws of the land.

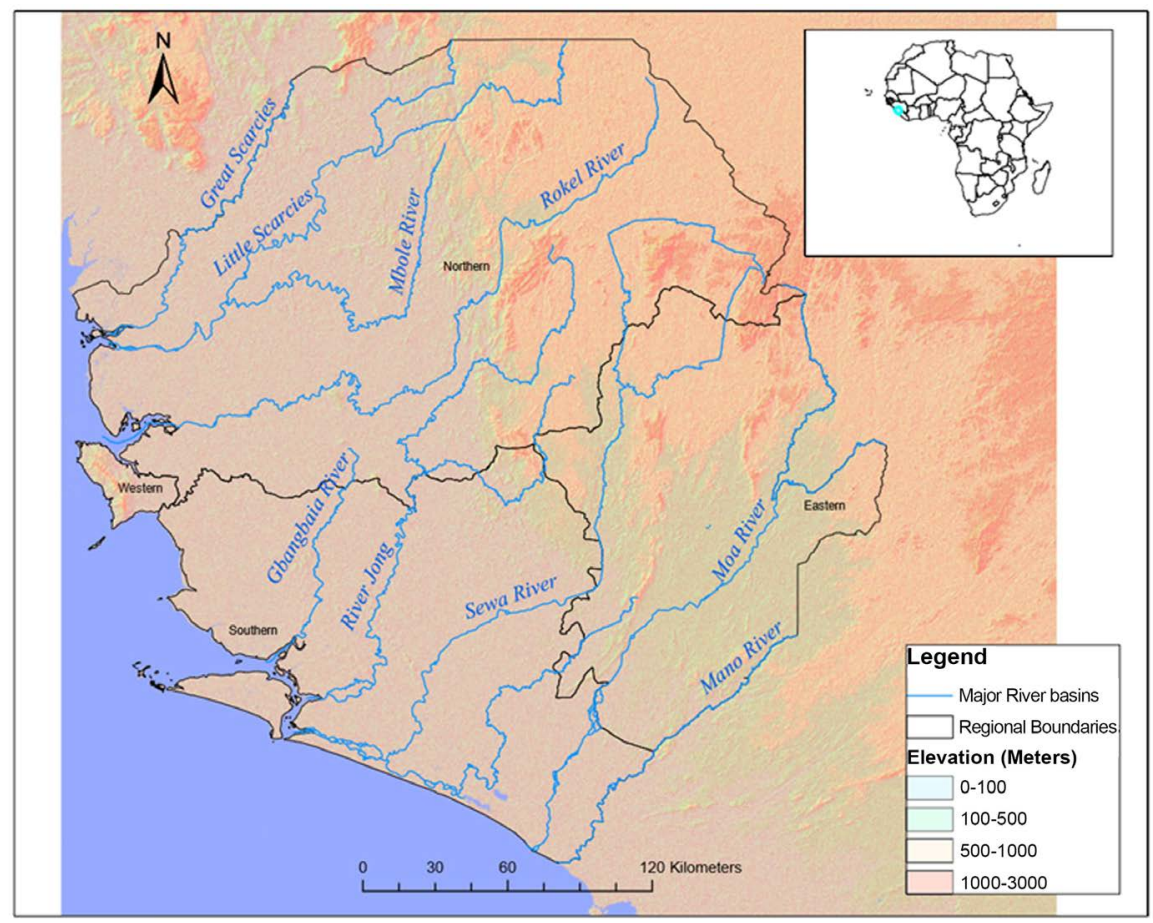

Figure 1. Map of Sierra Leone showing elevation, major rivers, and regional boundaries. 
The Legislature, led by the Speaker of the House, has the nation's law makers who also approve the President's major appointments and policies with the exception of Executive Orders. In the devolution of power to local governance, the Local government is linked to the central government through the Ministry of Local Government and has 22 District Councils. The Paramount Chiefs serve as the traditional heads of each Chiefdom. The Paramount Chiefs have Chiefdom Speakers as their deputies, followed by Section Chiefs, Town Chiefs, Chiefdom priests, and Tribal Heads [7].

Sierra Leone's legal system has four main sources of law enforcement [7]; the Constitution, common law, statutory law, and customary law. The Constitution is the supreme law of the land and all other laws derive from it. Sierra Leone introduced a constitutional government in 1863 and its constitution has evolved into many versions the most recent one being the 1991 constitution [7].

The Common laws of Sierra Leone enshrine the doctrines of equity, and the rules of customary law including those determined by the Superior Court of Judicature. According to Section 74 of the 1965 Courts Act, Common law enforced in England up to the $1^{\text {st }}$ January 1880 shall always apply in Sierra Leone [7].

Statutory laws derive from those adopted from England and those enacted by the House of Representatives in Sierra Leone's Parliament. The adopted laws were enacted by the British government and were applied directly to Sierra Leone when the country was a British colony. The nation's independence in 1961 ended enactment of statutory laws from the British government. Members of the Sierra Leone parliament became the law makers of the land.

In Customary law, which is largely unwritten, the rules are accustomed to specific communities within Sierra Leone. The community leaders develop rules and regulations to be accepted by the community members and then it becomes binding [7].

The centrality of water resources in the history of Sierra Leone is evident in most of the major events. Most major events occur either in pursuit or through the use of water resources. That explains the blue color in Sierra Leone's national flag (green, white, and blue). The green represents agriculture and forest resources and the white represents justice and peace [8].

The earliest settlers are known to have lived by water bodies for strategic reasons like transportation and wars [9]. In addition, their livelihood, arts and craft, and rituals were all dependent on territorial waters. The Shebro ethnic group, for example, has been known for fishing since the dawn of their existence.

The Atlantic Ocean had a major influence on the transatlantic slave trade. Sierra Leone became prominent in the history of slavery because of the strategic location of its natural harbors, which was a suitable docking point for the European voyages [10]. The Atlantic Ocean was also central in the selection of Freetown for the resettlement of freed slaves from Europe and North America as well as its designation as capital for the nation [11]. The Queen Elizabeth II quay is one of the largest harbors in the world serving as a major gateway for imports 
and exports and was a strategic location for the British Empire during the World Wars [12].

In Sierra Leone, most outbreaks are either water related or water borne. Sierra Leone has poor water supply and sanitary facilities. Most people rely on untreated water sources such as hand dug wells, springs, and streams for water use. This leads to cholera emergencies in most rainy seasons [13] [14]. Additionally, typhoid fever is very common among citizens. Sewage ends up into those water sources through surface runoff and base flow, introducing pathogens that cause the disease [15]. The high prevalence of Malaria also has to do with poor sanitation and stagnated water [15].

Natural resource needs were prominent in the war in the 1990s when it was mainly fueled by diamonds. Sierra Leone lists among countries with the largest deposit of diamonds in river beds, along the shoreline of major river basins, or in wetlands. Diamonds were used in exchange for weapons by the warring factions in the civil war. None certified diamonds from Sierra Leone were later labeled blood diamonds which made them illegal to buy. This policy helped bring the fighters to a negotiating table and the war ended in 2002 [16].

Albeit the centrality of water resources in major events and development efforts in Sierra Leone, the laws governing waters of Sierra Leone (WOSL) have not been an area of high priority. Sierra Leone is trailing behind many other developing countries in ensuring uninterrupted water supply, pollution management, and other beneficial uses of natural resources [17]. This work examines existing laws related to water quality in Sierra Leone. Two examples, evolution of water pollution laws in the US and the UK, are put in the context of how those laws may apply to Sierra Leone.

\section{The Problem}

Sierra Leone faces challenges in managing contamination, conservation, and supply of its water resources. As a result, the nation's authorities have, over the years, developed laws, policies, and regulations to curb these challenges. These laws have enhanced the establishment of agencies with specific mandates for water resource management. However, most of the efforts have been geared towards promoting water supply and maintenance of natural resource use. As a third world country, the nation still struggles to achieve social and economic development to the extent that environmental quality is inevitably a low priority. Hence, there has been minimal water pollution laws which scantily exist as sections or subsections in natural resource management laws. Consequently, even though the country has laws to manage its waters, the magnitude of pollution and the impact of its abatement efforts are not clear.

Poor sanitation is one of the major challenges facing the water sector in Sierra Leone. The Minister of water Resources in the Koroma-led government confirmed this in an interview with the Awoko Newspaper when he recounted that millions of citizens were yet to have access to improved water supply and sanita- 
tion [18]. Furthermore, there have been repeated cases of water borne disease outbreaks that source from poor sanitation in Sierra Leone. The Ministry of Health and Sanitation (MoHS) and the World Health Organization (WHO) have been reporting cases of cholera outbreaks since 1970, when 293 cases were recorded [2]. Since then, cases have frequently occurred during the rainy season and the worst outbreak occurred in 2012 when a record 22,885 cases with 298 fatalities were recorded. In that year, President Koroma declared a state of public health emergency and international partners helped the Government of Sierra Leone (GoSL) to reverse the outbreak.

These outbreaks have been attributed to poor sanitary conditions and practices that contaminate water supply sources. WHO (2013) report that $55 \%$ of people living in Sierra Leone had access to improved water sources in 2010, but only $13 \%$ had access to proper sanitation facilities in the same year. The WHO report also asserts that sanitation related disease outbreaks occur in the rainy season when surface runoff is high. The Millennium Challenge Coordinating Unit (2013) has also attributed diarrheal diseases to poor water and sanitation [19]. The problem has been reported to affect both urban and rural areas in Sierra Leone. The WHO and UNICEF (2014) assert that 22\% of the population who live in urban areas in Sierra Leone used improved sanitation facilities in 2012 and this is a $1 \%$ improvement since 1990. Unimproved facilities include poorly constructed latrines and open defecation [20].

According to the WHO/UNICEF report, only 7\% of the country's rural population used improved sanitation facilities in 2012 (improved by 2\% since 1990). More than half (54\%) of them used sanitation facilities that were unimproved whilst 39\% used open defecation, which was $26 \%$ in 1990 [20]. Bawoh and Koroma (2015) examined the people's knowledge, attitude, and practice of sanitation in one of the major cities in Sierra Leone, Bo. They concluded that the general level of knowledge on waste management was not adequate and it negated attitude and practice. Furthermore, there is a poor waste disposal system due to the weak infrastructure for waste management [21].

In Sierra Leone, there is minimal success rate of regulatory systems to manage waste disposal in municipalities and rural communities [22]. Managing the constant streaming of waste from residential, commercial, and industrial areas has gained low priority over the years. The sector has been manned by many governmental and private agencies none of whom has been successful [22]. The country lacks sewer systems for conveyance and treatment of sewage. The common practice of sewage disposal includes pit latrines, septic tanks and open defecation. When the pit latrines and septic tanks fill out, private contractors with cesspool bowsers are hired to remove and dump in public dumpsites. Most of the dumpsites are located along the shoreline of the ocean, rivers/streams, or in wetlands. This practice is common in urban areas of the country [23]. In rural communities, homeowners empty their sewage from pit latrines into dugout pits. In some cases, they would abandon a filled out pit latrine to construct a new 
one.

There is no known regulatory framework to manage stormwater runoff into waters of Sierra Leone (WOSL). In recent years, Sierra Leone's Environmental Protection Agency (EPA-SL) has been regulating construction companies through environmental impact assessment (EIA) licenses that have environmental management plans for construction waste. However, construction activities do not require any construction permit to protect WOSL thereby rendering susceptibility of those waters to sediment load. Sediment transport is a major problem whenever there is a major rain event. In addition, surface runoff in culverts and ditches conveys large quantities of solid waste into WOSL [22].

Sierra Leone imports petroleum products from neighboring African countries. Since oil and gas is not currently mined or refined in Sierra Leone, there are no known water quality issues related to the oil mines and processing. However, knowledge and attitude regarding disposal of waste oil and lubricants are poor. With the absence of stormwater management programs, the waste oil and lubricants end up in WOSL. Additionally, the nation has petrol (gasoline) stations in many locations. There is currently no available data on leaks from underground storage tanks. If any, these may lead to contamination of groundwater by petroleum hydrocarbons [24].

The major industries that affect water quality in Sierra Leone are mining, trade and commerce, transportation, construction, small scale manufacturing, and hospitality. The main pollutants of concern from mining are sediment, lubricants, and waste oil. In addition to mining companies, artisanal and small scale mining operations regularly introduce these wastes into WOSL.

Petty trading is a major industry in the informal sector of Sierra Leone. Citizens get most of their goods and services from this sector and, through this, they generate tons of waste. However, no data is available to determine the magnitude and dispersal of pollution from the waste, neither has there been any successful regulatory practice. The transportation industry (onshore and offshore) is mainly private and minimally regulated for waste disposal. Waste oil, lubricants, worn out parts and many other types of waste come from this industry most of which end up in WOSL.

Other than EIA requirements for construction companies, major construction activities by actors in the informal sector are not regulated for water quality purposes. Consequently, there is absence of beneficial management practices that minimize the impact of construction runoff. These construction activities are clearing vegetation and increasing the spatial extent of impervious areas.

Small scale manufacturing companies are mostly involved in beverage production. The main issue of concern is wastewater from the factories. However, most of these activities are regulated through compliance to EIA requirements. The question lies in the effectiveness of compliance. The same situation happens in the hospitality industry, where hotels and restaurants are a major concern when it comes to discharge of wastewater and food waste. 
Sierra Leone has vast arable land divided into five major cultivable ecologies: upland (4.42 million ha), bolilands (145,000 ha), riverine lowlands (130,000 ha), mangrove swamps (20,000 ha) and inland valley swamps (690,000 ha). This makes agriculture the biggest employing industry in the nation [25]. Rice is the nation's staple food and the most cultivated crop [26]. Even though, Sierra Leone depends mainly on imported rice [25], rice cultivation remains a major livelihood activity in the country [26]. Tillage is a major source of sediment erosion [27]. This means a major pollution from farming in Sierra Leone would be sediment load owing to the dominance of tillage farming. However, availability of data on sediment load from nonpoint sources, such as farming, is limited.

Since the 1920's, Sierra Leone has experienced major earth moving activities for the extraction of precious minerals including diamonds, rutile, bauxite, gold and small amounts of iron ore and limonite [28]. Diamond deposits are estimated at about 7700 square miles (about $25 \%$ of the nation's land area) in the southeast and eastern parts of Sierra Leone [28].

Diamond mining has been a source of sediment load and waste oil into major drainage basins in the country [29], the Sewa, Bafi, Mano, and Moa Rivers inclusive. Alluvial diamond mining includes instream mining, along floodplains, terracing forested areas, and mining in wetlands. Albeit these sources of water quality impairment, no available data exists, neither are major regulations, except for EIA requirements that came into force in 2000. Gold production from alluvial deposits [28] is also a major source of sediment load into WOSL. Few gold mining companies secure EIA license in addition to the large number of unregulated artisanal and small scale mining activities.

Bauxite from Sierra Leone is mined mainly in the southern region and it is not clear whether the mine wastes are subject to any regulatory standards for water quality. Sierra Leone is known for its particularly high-grade rutile, also from the southern region. It is the largest natural reserve in the world and accounting for a third of the total world production [28]. The activity involves major earth removal including relocation of whole villages and creation of large ponds from dredging. The company has been embarking on rehabilitation and land reclamation exercises, according to its 2016 report [30]. However, no record was found on water pollution regulations and compliance.

Iron ore mining has involved drilling and blasting of hills in northern Sierra Leone with stockpile of mine tailings. Recently, companies have environmental management departments that institute beneficial management practices, mainly sediment retention ponds. However, this may not be enough. The Tonkolili River, for example, has been extremely turbid following operations in Ferengbeya in the Bumbuna area.

\section{Summary of Laws Related to Water Quality in Sierra Leone}

In continuation of President Kabbah's Poverty Reduction Strategy Paper (PRSP), the Koroma-led government's Agenda for Prosperity (AfP) sought to develop a 
national regulatory framework to contain pollution and other environmentally harmful activities [31]. These created the pillars for developing or strengthening of laws that address specific environmental issues and water quality is one of those key issues. Under the water sector challenges, the agenda includes careful management as a priority for minimizing threat to water quality from population growth, increased industrial activities, poorly managed urban development, increased damming, industrial scale agriculture, and environmental degradation causing soil erosion, drainage of wetlands, pollution of rivers, and the rapid increase in the number of mining companies. One of the sector objectives is to develop comprehensive plans for the integrated management and efficient use of water resources. The objective emphasizes sustainable water use and management through the requirements for beneficial uses such as agriculture, fishing, drinking, mining, energy, tourism, and natural resource conservation [32].

In 2016, the Ministry of Water Resources drafted a bill entitled "The National Water Resource Management Act”, in collaboration with implementing partners. The goal of the act is to provide for the equitable, beneficial, efficient, and sustainable use and management of the country's water resources; to establish a National Water Resource Management Agency; to provide a Water Basin Management Board and Catchment Water Resource Management Committees for the management of the water resources and for other related matters.

Part VII of the Act is about water use and permit procedures. The provisions require permit for water use in all major categories including domestic, commercial, municipal, industrial, agricultural, power generation, water transportation, fisheries, environmental, underwater wood harvesting, and recreational water use. For whatever use, the agency shall take water quality as one of the requirements [Section 29(4)(e)] in granting permit. The act stipulates penalties for violators of the provisions of the permitting requirements.

In 2012, Sierra Leone's parliament enacted the National Protected Areas Authority and Conservation Trust Fund (NPAACTF) being an Act to provide for the establishment of the NPAACTF, to promote biodiversity conservation, wildlife management, research, to provide for the sale of ecosystems services in the national protected areas and to provide for other related matters. A key element of relevance to water quality is the development of buffer zones defined as areas of land one mile in width surrounding each National Protected Area.

The petroleum exploration and production Act of 2011 defines pollution as any direct or indirect alteration of the physical, thermal, chemical, biological, or radioactive properties of any part of the environment that affects any beneficial use adversely, to cause a condition which is hazardous to public health, safety, or welfare, or to animals, birds, wildlife, fish, or to plants. Territorial waters, under this Act, refers to the sea and inland waters, and territorial sea means any part of the open seas within twelve nautical miles of the coast of Sierra Leone measured from the low water mark.

The EPA-SL Act of 2008 and 2010 repealed but incorporated the 2000 Envi- 
ronment Protection Act. According to this Act an EIA is demanded for certain types of activities. A company or project shall be allowed to commence its operations only after the issuance of an EIA license, which approval is contingent upon a submitted EIA report. The EPA-SL Board may disapprove issuance of license if it envisages that the company's activities would have adverse effects on the environment and the community. Projects that have the potential of directly or indirectly affecting water pollution will require a comprehensive environmental management plan that minimizes the likelihood of this to occur or, in the event of occurrence, such project must have realistic mitigation measures.

The Mines and Minerals Act of 2009 repealed the Mines and Minerals Act of 1994 and the Commission for the Management of Strategic Resources, National Reconstruction and Development Act of 1999. The act addresses water quality issues related to mining activities in the nation including any freshwater dam and the waters impounded thereby to be left intact on cessation of operations or termination of a mineral right. No holder of a mineral right shall dredge any river, stream, watercourse, pond, lake or waters of the continental shelf or undertake any activity preparatory to or relating to dredging including flooding of an area without a dredging permit granted by the Minister. Any person who contravenes this provision commits an offence and shall be liable on conviction to a fine not less than three hundred United States Dollars, or its equivalent in Leones for every day during which the offence is committed.

The goal of the Marchant Shipping Act of 2003 is to consolidate the laws relating to the registration of ships, the regulation of shipping, the maintenance of safety at sea and the marine environment, and to provide for other related matters. The Act applies to both Sierra Leonean ships wherever they may be and non-Sierra Leonean ships while in a port or place in or within the territorial and other waters under the jurisdiction of Sierra Leone and to masters and seamen employed therein. By definition of this act, Sierra Leone waters include internal waters, inland waters, and the territorial sea of Sierra Leone. Internal waters include all waters landward of the territorial sea baselines of Sierra Leone and which are navigable.

Under this act, "damage to the environment" refers to physical damage to human health or marine life or resources in coastal or inland waters or areas adjacent thereto, caused by pollution, contamination, fire, explosion or similar major incidents. Up to eight sections address the issue of pollution from vessels.

\section{Review}

\subsection{Benefits of Strengthening Water Pollution Laws in Sierra Leone}

In the $21^{\mathrm{ST}}$ century, Sierra Leone is part of a global community that promotes sustainable development. There has been increasing awareness that poverty alleviation and economic development cannot go without sustainable environmental quality [33]. There is need to prioritize safe disposal of waste to prevent 
pollution of WOSL. When the sources of pollution are reduced to acceptable levels, the GoSL will be relieved of the burden of high spending in managing water pollution related health problems [34]. These pollution prevention steps will keep the nation's scenic rivers, lakes, and oceans intact for tourist attractions. They will also boost markets for contaminant-free sea food and biodiversity conservation. These will generate high paying jobs and improve the living standards of Sierra Leoneans [34].

Thankfully, The GoSL has been investing efforts in these directions when it established the nation's first environmental protection policy in 2000 (revised into the EPA-SL Act in 2008/2010), the Ministry of Water Resources in 2013, and the National Water Resource Management Act, which will establish and maintain the National Water Resource management Agency. A unique strength is that most of the nation's natural resource laws have sections that ensure pollution prevention and control. This agency diversity of pollution prevention efforts ensures commitment from all sectors.

However, strengthening and/or expanding on those sections to address potential policy gaps would enhance achievement of those policy objectives. Currently, the main foundation of those existing laws is economic gratification from natural resources. In order to enhance and maintain clean water for citizens and resource conservation, the foundational structure of water pollution laws would evolve around all problems and opportunities that affect the resource, people's welfare, and aquatic life.

Water resources give Sierra Leone a great potential for deriving benefits from the tourism industry. The nation's pristine beaches, islands, mountains, and rich biodiversity [35] are sustained by major drainage basins that run through and support those crucial habitats on their way to the Atlantic Ocean. Example, recreational beaches along the Freetown peninsula display the colors of the Sierra Leone flag (Green, White, and Blue), starting with the forested mountains in the south, coupled with swamps that transition into the white sand at Number Two/Tokeh beach, and clear blue water in the north [36]. The Tiwai Island, 12 sq. $\mathrm{km}$ in area and located in the Moa River, is host to 11 primate species, over 135 bird species, numerous butterfly species (some of which have recently been discovered by science) and at least 627 known plant species. Tiwai is also home to the extremely rare and elusive pygmy hippopotamus [36].

Loma mountains forest reserve, about $346 \mathrm{~km}$ northeast of Freetown, is found on a range of hills of wide altitudinal range ( $400-1900 \mathrm{~m}$ ), the highest being Bintimani Mountain $(1945 \mathrm{~m})$. The mountain range serves as source of many watersheds in Sierra Leone. Sewa and Rokel Rivers are two major river basins that source from these mountain ranges. This Loma forest reserve has many bird species of which five are globally threatened. Ten species of primates and several other large mammal species occur at Loma. Sustaining these and many other tourism potentials in Sierra Leone, require policies and management efforts that prevent or mitigate point and nonpoint sources of pollution. 
Sierra Leone Government's effort to promote and develop the tourism industry has been limited for many years [37]. In 2010, the Office of the President reviewed the industry to improve policy and actions that match modern tourism and culture requirements. The recommendations made centrality on law reform with the view of promoting sustainable tourism to ensure economic growth, socio-cultural integration, and to promote Sierra Leone as an environmentally friendly destination [38]. These sustainability requirements strengthen the need to improve on water pollution laws more so when the tourism industry is heavily dependent on the nation's aquatic resources.

Strengthening the statutory provisions for stormwater quality will help promote public health in addition to sustainable natural resource use. This is because stormwater conveys sediment, solid waste, waste oil, and hospital waste into rivers, lakes, and the Atlantic Ocean in Sierra Leone. They are proven sources of illnesses either directly or through biomagnification [39]. Groundwater is also susceptible to contamination from sewage disposal, making its regulation crucial.

\subsection{Examples of Water Pollution Laws and Their Evolution over Time}

Pollution laws mostly evolve around problems that either lead to the pollution itself or were created by the pollution. History has shown that humans always continue to pollute the environment until a significant issue imposes the urgent need to develop laws that mitigate or minimize the likelihood of such pollution. Some of the issues include disease outbreaks, fire accidents, fatalities in fish and wildlife, and study reports that reveal imminent danger [40]. Below are examples of the evolution of water pollution laws in the US and the UK. The lessons learned from these two countries are that environmental laws are complex and yet cannot be excluded from the social and economic development efforts in a nation.

\subsubsection{Evolution of Water Pollution Laws in the United States}

Water pollution management in the US took prominence in the $19^{\text {th }}$ century when it became obvious that humans can render water bodies harmful by dumping waste materials [41]. Most of the significant milestones in the promulgation of laws and regulations for water pollution management were triggered by concerns that resulted from water pollution problems.

The multifaceted Anglo American Common Law generally refers to the unwritten law of England that was brought in to the American Colonies and enacted upon formation of the United States [42]. This law made it acceptable to dump waste into waterways as long as there was access to a water body and the disposal did not pose threat to property rights or public interest. In the $19^{\text {th }}$ century, this blanket amnesty to polluters started to change when local governments began enforcing legal authority due to serious water pollution problems within their jurisdiction. Entire rivers and watersheds became more and more polluted 
and more and more states created agencies with responsibility to regulate discharge of pollutants into their territorial waters. By the time the Federal government took over water pollution management, most of the states already had agencies charged with the responsibility of managing state waters.

Most of the water pollution efforts were driven by public health concerns [43]. This is why most of the water pollution management agencies were hosted in state public health departments [43]. The primary public health concerns were health issues caused by disposal from sanitary sewers, municipal waste treatment plants, and industries dumping large loads of raw organic waste into waterways.

By the early $20^{\text {th }}$ century, diseases like cholera and typhoid fever were linked to drinking contaminated water. The U.S Public Health Service (PHS), in 1912, published their report of an investigation that was commissioned by Congress. This triggered collaborative efforts between the PHS, states, and local public health departments to develop national standards for chlorination and other treatments of public drinking water supplies [43].

Another significant issue that necessitated water pollution laws was navigation [44]. By 1866, Congress enacted the first federal water pollution control law which became the Rivers and Harbors Act of 1899 and, later, the Refuse Act. The law charged the Army Corps of Engineers with the responsibility of preventing the dumping of materials that might impede navigation into the harbors of New York City. This regulatory authority was, in 1890, extended to cover the harbors of the entire nation and further extended, in 1899, to include all navigable waters and their tributaries. This time, the law was taken beyond the navigability limit and included all matters of discharge into national waters. The only exception was liquid waste from municipal sanitary and storm sewers [43].

Oil pollution was another issue that led to promulgation of water pollution laws in the US. It became important when the nation saw repeated incidents of impairment from oil discharge to public beaches. Oil pollution posed health threat to key shellfish species and rendered the waters unfit for bathing. Fire hazards around harbors and docks also became common. All of these led to the enactment of the Oil Pollution Act of 1924, which made it unlawful for dumping of oil into coastal waters. The Secretary of War was given the authority to enforce this law. The law was later expanded to cover other hazardous substances. In 1972, this law became part of the Clean Water Act [43].

Despite the Oil Pollution Act of 1924, Federal laws did not require states to ensure safety of waters for citizens and, hence, no regulation for oil discharge into inland waters existed [45]. There were several river fires, Cuyahoga River fires of 1952 and 1969 listing among them. The 1952 fire resulted from unregulated oil discharges, allowing the oil to accumulate into thick blankets over the surface. The fires had great publicity and laid the foundation for the Federal Water Pollution Control Act [45].

The next era of water pollution management saw emergence of interested parties for different aspects of water quality management. There was growing pres- 
sure from fish and wildlife specialists who saw water pollution as a major issue that required regulation to enhance deterrence. Some members of congress saw the need to broaden federal involvement into water pollution management [43].

The outcome of a 1935 national conference on water pollution and recommendations from the advisory committee of the National Resources committee inspired a proposed bill on water quality management but did not pass in Congress. Several other bills did not meet common interest to pass through both houses of Congress. One major concern was drawing a line between state and federal management levels. In 1938, President Roosevelt vetoed a bill that passed though both houses on the pretext of separation of powers. He argued against one of the provisions that he thought conflicted with the prerogatives of the Executive Branch, albeit his deference to the general popularity of the bill [43].

When the world wars started, attention was diverted from water pollution management to war efforts. There was great investment in technologies that used mineral resources to fight in the wars. These practices led to further pollution of the nation's waters. Several legislations to prevent pollution from these sources were proposed during the war and immediately after but, most of them did not pass through either houses of Congress. Not until in 1948 when the first Federal Water Pollution Control Act was signed by President Truman as a five-year management strategy until reauthorization of the Act was required in 1953 [46].

The primary focus of the Federal Water Pollution Control Act was to encourage water pollution control at state level. Authority was not granted to the Federal government for water pollution control except for investigations, research, and surveys. Part of the Federal role was for the Federal Works Administrator to assist states, municipalities and interstate agencies to construct treatment plants and help prevent discharges of inadequately treated sewerage into other waters and tributaries. Additionally, the Surgeon General, had authority, under this law, to develop programs that would help eliminate or reduce pollution of interstate waters and tributaries and for improving the sanitary conditions of surface and underground waters [43].

The Federal Water Pollution Control Act was the first major US law that aimed at addressing pollution of the nation's waters. Over the years, this Act has been modified and expanded to meet changing demands as well as overcoming implementation constraints. In 1956, Congress amended the Act to provide grants to States and localities for construction of wastewater treatment plants with cost sharing between states and the Federal Government [47]. This amendment created a management mechanism, the "enforcement conference", which authorized the Federal Government to call a conference of Federal, State, and local authorities and polluters when serious water problems occurred across State boundaries. Either the responsible Federal agency or the affected state governors could call on a conference of the affected Federal agencies, state and local officials, identified polluters, and other interested parties to negotiate clean-up 
plans. However, this program was not successful due to problems with the enforcement conference mechanism. The act was amended again in 1961 to expand Federal enforcement powers and support for state and interstate pollution control and to include all navigable waters [43] [47].

In 1965, Congress passed the Water Quality Act [48] under which water quality standards were established. States were required to file implementation plans to meet these standards subject to Federal review, and plans to meet them. Unlike previous laws that focused only on eliminating discharges that potentially threatened human health through contamination of drinking water and food, the Water Quality Act demonstrated an increased concern over protecting aquatic ecosystems and beneficial uses such as swimming and fishing. This act created the Water Pollution Control Administration within the U.S. Department of Health, Education, and Welfare. In 1966, the Clean Water Restoration Act prescribed a fine of $\$ 100$ per day to be levied on any polluter who failed to submit reports required by law [49].

Congress passed the Water Quality Improvement Act in 1970 [50] to prohibit the discharge of harmful quantities of oil into or upon the navigable waters of the United States or its shores. The Act applies to both offshore and onshore facilities and vessels, and also provides for regulation of sewage disposal from vessels. In this same year, President Richard Nixon signed an Executive order that created the Environmental Protection Agency (EPA), responsible for consolidating all the Federal Government's pollution control laws.

By 1972, Congress tabled before President Nixon an amendment of the Federal Water Pollution Control Act. The amendment, S. 2770-the Federal Water Pollution Control Act Amendments of 1972, was a comprehensive revised and recodified version of the Federal Water Pollution Control Act [43]. President Nixon withheld approval of the bill, reasoning that the bill's intent, though laudable, was outweighed by its unconscionable $\$ 24$ billion price tag. He thought spending in this sector had compromised other equally important sectors [51].

However, Congress overrode President Nixon's veto and passed the amendment into law which later became the Clean Water Act (CWA). The purpose of the CWA is to restore and maintain the chemical, physical, and biological integrity of the Nation's waters [52]. It sets targets of waters becoming fishable and swimmable, and the elimination of pollution in all navigable waters of the United States. The CWA was in response to many litigations that claimed unlawful discharge of pollutants under the Rivers and Harbors Act [43].

The CWA was amended in 1977 and gave EPA the authority to implement pollution control programs and standards that regulate industrial discharge, set water quality standards for contaminants in surface waters, make it unlawful for any person to discharge without permit into navigable waters, fund construction of sewage treatment plants under the construction grants program, and plan to address nonpoint source pollution [53]. Congress included new provisions to address 65 toxic pollutants using best available technology (BAT) and to be 
achieved by July 1, 1984. Congress also established new best conventional pollutant control technology (BCT) limitations and required achievement by July 1, 1984. The 1977 amendments also added provisions for best management practices, removal credits for pretreatment standards, and modifications of BAT requirements for nontoxic pollutants. These provisions have been going through modifications in adhering to lessons learned and to meet emerging technologies.

The CWA has two important sections that are useful to the thesis of this article, point and nonpoint sources of pollution. The term "point source" means any discernible, confined and discrete conveyance, including but not limited to any pipe, ditch, channel, tunnel, conduit, well, discrete fissure, container, rolling stock, concentrated animal feeding operation, or vessel or other floating craft, from which pollutants are or may be discharged. This term does not include agricultural storm water discharges and return flows from irrigated agriculture [39].

Section 402 of the CWA requires that all construction sites one acre or greater of land, as well as municipal, industrial, and commercial facilities discharging wastewater or stormwater directly from a point source into waters of the US must obtain permission under the National Pollutant Discharge Elimination System (NPDES) [54]. Section 404 establishes a program to regulate the discharge of dredged or fill material into waters of the US, including wetlands. Activities in waters of the United States regulated under this program include fill for development, water resource projects (such as dams and levees), infrastructure development (such as highways and airports) and mining projects. Unless an exemption is stipulated, all activities of this nature require a permit before proceeding [39].

Nonpoint source pollution, unlike pollution from industrial and sewage treatment plants, comes from many diffuse sources. The 1987 amendments had Section 319 address the creation of nonpoint source management programs. This section addresses the need for greater federal leadership to help focus state and local nonpoint source efforts. Under Section 319, states, territories, and tribes receive grant money, which is $60 \%$ of funding that match $40 \%$ contribution from the local partner, to support a wide variety of activities including technical assistance, financial assistance, education, training, technology transfer, demonstration projects, and monitoring to assess the success of specific nonpoint source implementation projects [53].

Over the years, implementation of water pollution laws and regulations in the US has unveiled a variety of complexities that triggered controversies and adjustments in the laws. Moreover, the US has learned that enforcing pollution abatement cannot be separated from satisfying society while at the same time striving to advance economic development. These realities were the motivation behind less punitive measures in pollution prevention. Section 319 in the Clean Water Act is an example, which has an objective of encouraging an integrated approach of pollution abatement [53]. 
Albeit all the awareness and progress made, the US still has many citizens who struggle with rationalizing the need to have environmental laws as part of the development equation. Those citizens believe environmental laws kill jobs and discourage economic development. Consequently, the country is deeply divided along political lines as dictated by these policy debates [55]. The lesson learned is that even though environmental laws (such as water pollution laws) are inevitable, their coding should be unique to the social, cultural, and economic wellbeing of the affected population. These laws can be successful when they are dynamic in response to changing trends in the population.

\subsubsection{Evolution of Water Pollution Laws in the United Kingdom}

Major of the milestones in the UK's water pollution management were determined by sanitation problems, the industrial revolution in the 1800s, post-World War reconstruction needs, and the late $20^{\text {th }}$ century sustainable development era [56]. The UK's water pollution issues became a major concern in the late $18^{\text {th }}$ century when the volume and complexity of waste increased in major cities. Processing of cotton and wool, and production of iron and steel created the need to concentrate factories near water bodies to help power water wheels; this resulted in booming populations in major cities [57]. This population rise led to increase in the quantity of domestic sewage as well as solid and liquid industrial waste, most of which ended up in river systems. The resulting effects were stinking cities, poor water quality, and loss of aquatic life [58]. These issues created public health concerns and the need for proper waste disposal became important.

In the 1800 s, it was widely believed that cholera was spread by "miasma" (stinking gases in the air). Poor waste disposal led to decomposition and subsequent emission of gases with offensive odor (the "miasma"). By the mid-19 $9^{\text {th }}$ century, Dr. John Snow disputed the miasma theory when he reported the cholera pathogen in the human body was spread through contaminated water. His theory became a significant historical milestone in the promulgation of water pollution laws in the UK [58].

John Snow investigated the cause of the cholera outbreak at locations close to his residence in the Soho district. He made a map showing the 13 public wells and their association with the known cholera deaths in the area; he saw a pattern. There was spatial clustering of cases around one particular water supply source on the southwest corner of the intersection of Broad Street and Cambridge Street. He then carried out microbiological tests on water samples from wells in the area using a microscope. He found a strange microorganism in the Broad Street samples and concluded it was responsible for the cholera outbreak.

Snow launched an advocacy for shutdown of the pump at Broad Street but this met resistance from authorities who were skeptical of his findings [59]. His theory faced resistance mainly because "miasma" was supported by leading public health professionals at that time. Nonetheless, Snow continued building his evidence and, 22 years later, presented his evidence based theory to the St James 
Parish Vestry, the body responsible for the health of Soho citizens. Even though his evidence was found to be convincing, authorities still held on to the concept of miasma being responsible for cholera. He did not live to see the triumph of his alternative theory when he died in 1858 [59]. His theory became popular when River Thames was rendered a major source of cholera deaths; politicians were forced to act and solve London's water pollution problems [60].

This growing pressure led to the formation of two Royal Commissions on River Pollution in 1865 and 1868. The reports led to the enactment of the Public Health Act of 1875. The Act recognized public health promotion as a national responsibility and ushered in local health administrations with authority to manage treatment and disposal of sewage [60].

The 1875 Public Health Act was followed by the River Pollution Prevention Act of 1876 that served as the basis of all legal action with regard to river pollution until 1951. The Act delineated four main categories of pollutants that informed actions under which Great Britain authorized jurisdiction to hold violators accountable [61]: solid refuse of manufactories, manufacturing processes and quarries, rubbish and cinders, and any other waste or putrid solid matter; sewage matter, whether solid or liquid; poisonous, noxious, or polluting liquids proceeding from factories and manufacturing processes; and solid or liquid matter proceeding from mines which is poisonous, noxious, or polluting, or interferes with the flow of the water.

Part I has provisions that prohibit discharge of solid matter into streams. Part II has provisions that prohibit sewage discharge into streams through sewers. Part III prohibits discharge into streams through drainage from manufactories. It also has provisions that prohibit drainage into Streams from mines of any solid matter in such quantities that can create pollution problems.

Part IV is the administrative aspect of the act that, stipulating that all sanitary or other local authority having sewers under their control shall give facilities for enabling manufacturers within their district to carry the liquids proceeding from their factories or manufacturing processes into such sewers. Additionally, the law under this section stipulates that no sanitary authority shall be required to give such facilities as aforesaid where the sewers of such authority are only sufficient for the requirements of their district, nor where such facilities would interfere with any order of any court of competent jurisdiction respecting the sewage of such authority. Part IV also has provisions for power of sanitary authorities to enforce the act in cases of violations under the provisions of this section.

Part V has provisions that define the application of the act to Scotland. Application of the act to Scotland required slight modifications in order to fit into its administrative and legislative structures. Similarly, part VI has provisions that define the application of the act to Ireland as it fits into the legal requirements of that part of the country.

The steps taken during this period, enhanced the creation of institutions that were charged with the responsibility of resolving water pollution problems. The 
Royal Commission on Sewage Disposal was responsible for investigating and reporting on methods of sewage treatment. The reports included sewage treatment methods that satisfied existing laws, rules to be adopted if more than one method proved suitable, and recommendations that would inform proper treatment and disposal of sewage [61]. These reports formed the basis of modern sanitary engineering practice.

The industrial revolution was another turning point for water pollution laws when emerging technologies that pinpoint sources of industrial pollutants gave way to the era of source specific pollution laws [62]. The laws in this era targeted treatment methods that rendered wastewater safe for disposal. The Public Health Act of 1936, for example, prevented a local authority from discharging untreated wastewater into a stream. The Public Health Act of 1937 (Drainage of trade premises) is another example that enacted the "consent to discharge arrangement" in which industries were allowed to discharge into public sewers depending on the nature and composition of their effluents.

The River (Prevention of Pollution) Acts of 1951 and 1961 were enacted in order to cohere existing laws for protecting rivers from pollution. In 1974, the Control of Pollution Act was passed to help strengthen the laws that aimed at preventing water pollution. In 1989, the UK government saw the need to establish a National Rivers Authority (NRA), under the Water Act of 1989, to control and regulate the aspects of the waterways in England that dealt with pollution [63].

The Environment Act of 1995 brought in the Environment Agency with responsibility to deal with all aspects of the environment, repealing and replacing the NRA. These changes had their associated parallel changes in Scotland and Northern Ireland. Despite these changes, the Water Resources Act of 1991 consolidated existing pollution laws, making it an offence to discharge anything into a river without a permit from the Environment Agency or one of its equivalent bodies in Scotland and Northern Ireland [64].

Recently, the Waters Act of 2003 brought in new legislations concerning the UK's rivers and canals with primary focus on enhancing water conservation practices by companies, and to give the Environment Agency the power to alter or revoke the license of a water abstraction company who harm the environment. Additionally, the Marine and Coastal Access Act of 2009 serves to protect the UK's waters including provisions to safeguard the British coastal environment [63].

With globalization in the late $20^{\text {th }}$ century, the world became increasingly connected and sustainable development became the driving force behind pollution laws. Increasing awareness in environmentalism brought in concepts like "The Silent Spring", "Tragedy of the Commons", and "The Limit to Growth". England is among the countries that led development of both domestic and international laws to protect the environment. These modern laws take into account the social, economic, and ecological significance of issues surrounding 
pollution [56].

\subsection{Comparing Pollution Laws in Sierra Leone to Those in the US and the UK}

Current water pollution management in Sierra Leone is similar to those in the US [65] and the UK in the 1800s. Compared to the US, Sierra Leone was once a British colony and common Law is also part of the nation's legal system [7]. Civil law suits dealing with waste disposal into water ways, especially in rural areas and communities within cities, are settled on the basis of common law. The chief or tribal head settles such disputes based on tradition and common sense.

While statutory laws exist to discourage discharge of pollutants into WOSL, it is not widely known if records of major criminal or civil law suits that are directly related to pollution of the nation's waters exist. Since most of the statutory provisions for clean water have not been tested in court, it seems unclear whether they may be inadequate; future law suits will determine gaps in their legal extent of enforcement.

Compared to the UK in the 1800s, contemporary dwelling of people along water bodies in Sierra Leone is primarily due to rural-urban migration. This practice became prevalent during the civil war in the 1990s when people fled war zones and moved into safer cities. Overpopulation of major cities led to backfilling of coastal areas as well as wetlands and ponds for dwelling purposes [23].

Unlike the UK and the US, when they prioritized water pollution abatement because of public health disasters in their dawn of water pollution laws, no record is available in Sierra Leone that shows statutory priority of public health as a result of water pollution. Even though records show prevalent water borne diseases [2] compared to those in the UK and the US in the late $18^{\text {th }}$ century, government policy has been more reactive as well as little to no efforts in promulgation of laws that minimize the likelihood of the problem.

Sierra Leone seems to be in similar $18^{\text {th }}$ century scenario as UK/USA in that disposal of waste, directly or via some conveyance, into waterways is met with little to no law enforcement. In situations where there are existing laws, they are either weak or barely known. The current belief systems with regard to pollution have similarity to the "Snow vs. miasma" situation in the $19^{\text {th }}$ century UK. It is widely accepted among most of the $57 \%$ illiterate population [66] that supernatural forces are responsible for poor health. This is also the case for some in the literate population. Nonetheless, the nation has seen disasters related to water and sanitation in several years [2] and this water borne and water related diseases have ranked among the major public health issues in several decades [2]. Albeit these repeated outbreaks, Sierra Leone has not commensurately responded with pollution laws to eliminate their sources and likelihood.

Similar to war efforts in the US during the world wars, natural resources played major role in promoting Sierra Leone's civil war in the 1990s. War-driven diamond mining [67] contributed sediment load into rivers adjacent to mine 
sites. Sierra Leone's civil war left great reconstruction needs similar to those faced in the UK after the world wars. Thankfully, awareness of the importance of sustainable development has seen political will in incorporating environmental management into most of the nation's reconstruction efforts.

In the US, water pollution laws have been successful partly because they reflect the diversity in populations of the country. At the local level, for example, indigenous communities in Native American nations promulgate water laws in view of water as a cultural resource. These do not change in state laws of territorial waters, and Federal regulations reflect these diversities as well [68]. Similar consideration is a strong basis of the UK's water pollution laws as seen in statutory provisions taking into account the differences between Scotland, Ireland, and England.

Sierra Leone is well known for great tolerance in ethnic and religious diversities as evident in most of the nation's legal and administrative systems. If these existing administrative requirements in Sierra Leone (customs and traditions, religious/ethnic diversity, local government, and central government) are utilized for the purpose of promulgating and enforcing water pollution laws, there can be a promise of improved water quality in WOSL. This will subsequently lead to improved public health and living standards of the people.

\subsection{Case Analysis: The US Clean Water Act}

Efforts to improve water pollution abatement in Sierra Leone could cue from the structure and lessons learned in implementing the US CWA. The main commonality would be the resource itself and its component types-oceans, rivers, lakes and wetlands. In addition, humans the world over depend on these resources for food, energy, transport, and recreation. In the pursuit of these benefits, people contaminate the waters either deliberately or accidentally and pose health threats to humans and other organisms. Laws such as the CWA, promote deterrence of activities that cause such contamination to protect public health and the environment. On the other hand, delineating statutory requirements for regulating human activities, like point and nonpoint sources of pollution, would depend on the nature of such activities that discharge pollutants into WOSL. It will also depend on the people's priorities, cultures, and political will.

In Sierra Leone, water pollution laws are not integrated into one statute like it is in the US CWA; each statute has its unique regulatory and administrative arrangements for managing water quality as it applies to that sector. This type of statutory arrangement has strength in ensuring deterrence of discharge from all sectors whose activities threaten the chemical, physical, and biological integrity of WOSL. However, this fragmented statutory arrangement for water pollution abatement may render undue burden on actors whose activities are affected by synergistic relationships between sectors. Another disadvantage may be the existence of statutory gaps because agencies are primarily interested in those aspects that affect their mandate. In this regard, the existence of gaps in statutes makes enforcement complicated and difficult. 
In the definition of pollution in the EPA-SL Act of 2008 and 2010, there are provisions for administrative and funding arrangements to ensure enforcement. The agency has authority to develop and enforce water quality regulations and standards. However, there are no clear statutory provisions for point and nonpoint sources of pollution. Additionally, regulatory extent in terms of authority and coverage are not clearly defined. In the NWRMA, the act defines permitting requirements for beneficial water use in the nation. Section 29(4)(e) requires that the agency shall take water quality as one of the requirements for granting the permit. Like the EPA-SL laws, there is limitation in statutory provisions for point and nonpoint sources of pollution. These requirements are generally implied in the statute. The Mines and Minerals Act of 2009 is the only statute that defines permitting requirements for dredging and discharge of fill materials into WOSL, even though these requirements apply only to mining companies.

In the CWA in the US, the statutory provisions for point and nonpoint source pollution are clearly defined. The USEPA and the Army Corps of Engineers have authority to enforce those statutory provisions. Experiences in the US of complications and controversies in enforcing these water quality laws signify the need for well-defined and comprehensive permitting requirements for point and nonpoint sources of water pollution. Numerous lawsuits and settlements have dictated revisions and/or modifications of those statutory provisions [55]. One major area of controversy is defining the extent to which permitting requirements apply to Sections 402 and 404 of the CWA.

An example is a 2005 US Supreme Court case involving four Michigan wetlands lying near ditches or man-made drains that eventually emptied into traditional navigable waters [69]. In case number 04-1034, the United States brought civil enforcement proceedings against the Rapanos defendants, who had backfilled three of the areas without a permit. The District Court found federal jurisdiction over the wetlands because they were adjacent to waters of the US and held the petitioners liable for CWA violations. The Sixth Circuit maintained deference and ruled in favor of the United States on the basis that the sites had hydrologic connection to the nearby ditches or drains, or to more remote navigable waters. Similarly, the Sixth Circuit ruled in favor of the United States in case number 04-1384. The Carabell petitioners were denied a permit to deposit fill in a wetland that was separated from a drainage ditch by an impermeable berm. The court held that the wetland was adjacent to navigable waters.

Rapanos et al. appealed to the US Supreme Court in regard to the definitional limits of "adjacency" to waters of the US and claimed they did not require permit in this case. The Supreme Court arrived at a plurality issue with a 4-1-4 opinion split. Judgments were vacated and the two cases were remanded [69]. The USEPA and the Army Corps of Engineers have, over the years, integrated those court rulings into regulations that helped clarify definitions of point and nonpoint sources in the interest of all the parties involved. Ultimately, these definitions have guided permitting and compliance requirements as well as liability 
and compensation requirements.

In the US CWA, permits granted through the national pollutant discharge elimination systems (NPDES) cover stormwater discharged from medium and large municipal separate storm sewer systems (MS4s) located in incorporated places or counties with populations of 100,000 or more. Transportation authorities are also responsible for managing the stormwater runoff that discharges via regulated MS4s along streets, roads, and highways.

In Sierra Leone, urban populations range from about 6000 to about 1,000,000. Hence permitting requirements for municipalities could be scaled to the population density and structure of urban and rural areas in the country. The transportation sector has agencies such as the Ministry of Transport and the Road Transport Authority. There are key interest groups in the transport sector vehicle mechanics, Motor Drivers Association, and Bike Riders Association inclusive. A management system that integrates these interested parties may help minimize stormwater pollution from transportation.

Sierra Leone lacks the infrastructure that conveys stormwater through clearly defined storm drains into WOSL. This makes it difficult to adapt the US CWA's MS4 program. Nonetheless, municipalities and transportation authorities can generate funds through city rates and licenses to manage stormwater permit programs. If the chemical, physical, and biological integrity of WOSL become compromised from stormwater, poor water quality may compromise the health of the population and hurt the economy [39]. Ecologically, lack of stormwater management may compromise aquatic life and biomagnification may become a major issue. On the other hand, an effective stormwater management program will ensure benign water quality and also promote healthy terrestrial ecosystems [39].

The US EPA's Construction Stormwater General Permit (CGP) requires construction site operators to meet restrictions on erosion and sediment control, pollution prevention, and stabilization. In Sierra Leone, the potential culprits of erosion/sediment load and the pollution thereof are road construction companies, mining companies, and building contractors. Currently, major construction companies are required by law to conduct Environmental Impact Assessment (EIA) and pay the requisite license fees. An additional water pollution permit may increase burden and may not attract public interest. The recommendation is to revise the existing requirement into a new construction permit because not all activities may require an EIA but, all of them could meet some permitting requirement to protect the nation's valuable natural resources and the people's welfare.

Many Sierra Leoneans depend on open water bodies for consumption without prior treatment. Construction laws that minimize the likelihood of turbidity may protect the health of the population. Sediment load is a major issue in Sierra Leone, especially during storm events. During the rainy season, elevated turbidity in WOSL, road blocks, and landslides, are all common. 
The NPDES permitting program establishes discharge limits and conditions for industrial and commercial sources with specific limitations based on the type of facility/activity generating the discharge. Industrial activities include construction (5+ acres), oil \& gas industry, landfills, hazardous waste disposal, etc. In Sierra Leone, there are several commercial facilities operating as small businesses. They are everywhere in cities, small towns, and villages. They have a wide range of merchandize including groceries, restaurants, hospitality, home and office equipment, pharmaceuticals and personal care products, and electrical and electronics supplies. Additionally, there are small scale industries which are growing in number. There are several petrol (gas) stations all over the country. Waste dumpsites are managed by municipalities. All of these industries apparently discharge pollutants into WOSL. If not managed, they will continuously discharge those pollutants in quantities that potentially elevate contamination to disastrous levels for humans and aquatic life.

A general permitting in the different categories could be a good way to manage pollution from these sources. These small scale industries could fill a notice of intent (NOI) form based on categorization and the required fee to be assigned. These permitting requirements will reverse the likelihood of pollution and promote beneficial uses of the nation's waters such as drinking, fishing, swimming, agriculture, recreation, power generation, and navigation.

The NPDES permit establishes discharge limits and conditions for municipal wastewater treatment facilities in cities across the US. In Sierra Leone, publicly owned treatment works (POTWs) do not exist. Rather, the country has private cesspool emptying companies who transact with residents to transport sewage to dumpsites. The country has no sewer infrastructure; homes, institutions, and commercial places have pit latrines or septic tanks. The raw sewage is periodically dug out and dumped in wetlands with significant nexus to WOSL. Sewage is a major source of impairment to water bodies; dumping of raw sewage is believed to increase pathogen population in the water body and pose health threat to aquatic life [70]. It also increases oxygen demand and cause bioavailability of toxic pollutants. Appropriate compliance schemes could be developed for private cesspool disposal companies to serve in lieu of POTWs.

The NPDES permitting program regulates discharges incidental to the normal operation of a commercial (i.e., non-military, non-recreational) vessel when operating as a means of transportation. In Sierra Leone, the Queen Elizabeth II Quay receives cargos from many countries. Mining companies use the Atlantic Ocean to ship their minerals. Fishing vessels are always on shore of the nation's territorial oceans and inland waters. Sierra Leone's richness in fish resources attracts fishing vessels from a number of countries, in addition to local fishing boats. They are potentially major sources of waste that can pollute aquatic resources. Strengthening the current pollution abatement program for these vessels, through a special permitting program, will insure sustainable fishing and economic growth in Sierra Leone. 
The US CWA establishes a program to regulate the discharge of dredge and fill material into waters of the US, including wetlands. Currently, in Sierra Leone, dredge and fill materials are covered under mining and EIA licenses. It appears that no laws exist to discourage construction of homes on wetlands. In urban and rural areas, it is common practice to see backfilling of wetlands and use for dwelling, commercial, or recreational purposes. Wetlands are very important for flood control and maintaining the chemical, physical, and biological integrity of downstream waters [39]. These are necessary for the protection of homes and public health. Without these wetlands, there will be no natural filters to clean runoff before entering into WOSL. This may cause transportation of sediments, solid waste, sewage, bacteria, and toxic wastes into Sierra Leone's waters thereby causing impairments and problems for humans and aquatic life [39].

In the US CWA, Nonpoint source mainly includes agricultural runoff and irrigation return flows. Under Section 319 of the Act, the Federal government works with states, territories, and tribes to share the cost of managing water quality impairment from nonpoint source pollution. The 319 program includes a wide variety of activities such as technical assistance, financial assistance, education, training, technology transfer, demonstration projects and monitoring to assess the success of specific nonpoint source implementation projects.

In addition to agriculture, waste disposal in Sierra Leoneans is indiscriminate. The attitude towards waste is to trash anywhere expecting some authority to take care of it. There are very poor institutional arrangements for waste streaming in both urban and rural areas. Hence, identifying who pays for trash may be difficult. However, a nonpoint source program, such as the US CWA's 319 program, has a better chance of ensuring solution to this problem. Alternatively, waste disposal companies could be categorized as point sources of liter in cities and towns of Sierra Leone thereby enabling them to integrate the permitting requirements into their business models.

\section{Conclusions}

The objective of this work was to review existing water pollution laws in Sierra Leone to guide recommendations for areas that need strengthening. Sierra Leonean water quality laws were compared to those in the UK and the USA. The laws in those two countries have evolved since the 1800s and have improved significantly. However, enforcement has never been devoid of major challenges and controversies. The major turning points have been triggered by significant pollution events that compromised public health, aesthetic problems, biodiversity, tourism, and the general economic trends of the two nations.

Even though poor water quality has caused major public health problems, aesthetic issues, significant reduction in tourism, and biodiversity degradation, Sierra Leonean water quality laws have not followed similar trends as they did in the UK and USA. Water pollution laws became prominent in the early 2000s and 
had mostly been driven by natural resource exploitation. This is partly the reason why most of those laws are sections in statutes that promote natural resource management. The gap areas are usually handled by means of common law, which is largely unwritten.

For improved water quality laws in Sierra Leone, determinant factors need not only be natural resource management. Historical trends of water borne and water related diseases have shown that public health needs to be a major driver of amendments in the nation's water pollution laws. Other important drivers include aesthetics, biodiversity conservation, tourism, recreation, and the general outlook of the nation's economy.

\section{Conflicts of Interest}

The authors declare no conflicts of interest regarding the publication of this paper.

\section{References}

[1] Strezov, V., Evans, A. and Evans, T.J. (2017) Assessment of the Economic, Social and Environmental Dimensions of the Indicators for Sustainable Development. Sustainable Development, 25, 242-253. https://doi.org/10.1002/sd.1649

[2] WHO (2013) Cholera Country Profile: Sierra Leone. World Health Organization.

[3] Sibanda, T., Selvarajan, R. and Tekere, M. (2015) Urban Effluent Discharges as Causes of Public and Environmental Health Concerns in South Africa's Aquatic Milieu. Environmental Science and Pollution Research, 22, 18301-18317. Https://doi.org/10.1007/s11356-015-5416-4

[4] Day, S.J., Carter, R., Dumble, P., Juana, M., Kamara, I. and Mansaray, A. (2015) Strategy for Water Security Planning Volume I. Ministry of Water Resources Sierra Leone, Freetown.

[5] SSL (2016) Sierra Leone 2015 Population and Housing Census: Provisional Results. Statistics Sierra Leone, Freetown.

[6] NEC (2018) NEC: Boundary Delimitation. National Electoral Commission, Freetown.

[7] Kabbah, H. (2014) Update: Sierra Leone Legal System and Legal Research. Hauser Global Law School Program, New York University School of Law.

[8] World Atlas (2016) Sierra Leone Flag and Description. http://www.worldatlas.com/webimage/flags/countrys/africa/sierraln.htm

[9] Kup, A.P. (1960) An Account of the Tribal Distribution of Sierra Leone. JSTOR, 60, 116-119. https://doi.org/10.2307/2797173

[10] Kelley, S.M. (2017) The Voyage of the Slave Ship Hare: A Journey into Captivity from Sierra Leone to South Carolina. The William and Mary Quarterly, 74, 172-175. https://doi.org/10.5309/willmaryquar.74.1.0172

[11] Anderson, R. (2013) The Diaspora of Sierra Leone's Liberated Africans: Enlistment, Forced Migration, and "Liberation" at Freetown, 1808-1863. African Economic History, 41, 101-138.

[12] Stewart, A. (2017) The Scond World War and the "Quiet Colony of Sierra Leone". In: Jackson, A., Khan, Y. and Singh, G., Eds., An Imperial World at War-Aspects of the British Empire's War Experience, 1939-1945, Routledge, New York, 10-29.

[13] Nguyen, V.D., Sreenivasan, N., Lam, E., Ayers, T., Kargbo, D., Dafae, F., Jambai, A., Alemu, W., Kamara, A., Islam, M.S., Stroika, S., Bopp, C., Quick, R., Mintz, E.D. 
and Brunkard, J.M. (2014) Cholera Epidemic Associated with Consumption of Unsafe Drinking Water and Street-Vended Water-Eastern Freetown, Sierra Leone, 2012. The American Journal of Tropical Medicine and Hygiene, 90, 518-523. https://doi.org/10.4269/ajtmh.13-0567

[14] Mansaray, A.S., Borsuah, J., Gogra, A.B., Fofana, B.P. and Koroma, B.M. (2017) The Safety of Water Supplied at Njala University, Njala Campus. Natural Resources, 8, 81-93. https://doi.org/10.4236/nr.2017.82006

[15] WHO (2015) World Health Statistics. World Health Organization (WHO), Luxembourg.

[16] Davies, V. (2000) Sierra Leone: Ironic Tragedy. Journal of African Economics, 9, 349-369. https://doi.org/10.1093/jae/9.3.349

[17] UNDP (2016) Human Development Report. United Nations Development Program, New York.

[18] S. L. Minister of Water Resources (2017) Water and Sanitation in Sierra Leone with the Minister of Water Resources.

[19] MCC (2013) SIierra Leone Constraints Analysis Report. Government of Sierra Leone \& Millennium Challenge Corporation of the USA.

[20] WHO \& UNICEF (2014) Progress on Sanitation and Drinking Water-2014 Update. WHO Library, Geneva.

[21] Bawoh, B.A.A. and Koroma, S. (2015) Urban Sanitation in Bo City-A Study on Kowledge, Attitude, and Practices. Bo City Council and Welthungerhilfe, Bo.

[22] Gogra, A.B., Yao, J., Kabba, V.T.S., Sandy, E.H., Zaray, G., Gbanie, S.P. and Bandagba, T.S. (2010) A Situational Analysis of Waste Management in Freetown, Sierra Leone. Journal of American Science, 6, 124-135.

[23] Mansaray, A.S., Massaquoi Senior, A.-B., Samai, I.J. and Koroma, B.M. (2015) Exposure to Dioxins and Furans at the Bormeh Kingtom Dumpsite in the Western Area of Sierra Leone. Natural Resources, 6, 491-501. https://doi.org/10.4236/nr.2015.69047

[24] USEPA (2018) Underground Storage Tanks (USTs). https://www.epa.gov/ust

[25] Sankoh, A.I., Whittle, R., Semple, K.T., Jones, K.C. and Sweetman, A.J. (2016) An Assessment of the Impacts of Pesticide Use on the Environment and Health of Rice Farmers in Sierra Leone. Environment International, 94, 458-466. https://doi.org/10.1016/j.envint.2016.05.034

[26] Kamara, J.S., Leigh, A.U. and Cooke, R.A. (2015) A National Survey of Rice (Oryza sativa L.) Grain Quality in SIierra Leone II: Evaluation of Physical Grain Quality. African Journal of Food, Agriculture, Nutrition, and Development, 15, 10559-10577.

[27] Rocha Jr., P.R.D., Bhattarai, R., Fernandes, R.B.A., Kalita, P.K. and Andrade, F.V. (2016) Soil Surface Roughness under Tillage Practices and Its Consequences for Water and Sediment Losses. Journal of Soil Science and Plant Nutrition, 16.

[28] MoMMR (2018) Ministry of Mines and Mineral Resources. Government of Sierra Leone. https://slminerals.org/key-minerals/

[29] Suri, T. and Marx, B. (2014) The Growth Impacts of Diamond Mining in Sierra Leone. The International Growth Center. [Online]

https://www.theigc.org/project/the-growth-impacts-of-diamond-mining-in-sierra-1 eone/

[30] SRL (2016) Reports, Results and Presentations. Sierra Rutile Limited, Fretown.

[31] GoSL (2013) The Agenda Forprosperity: Road to Middle Income Process. Government of Aierra Leone (GoSL), Freetown. 
[32] Andersn, P.C. (2017) Sierra Leone Web-Laws. http://www.sierra-leone.org/laws.html

[33] EEA (2010) Chapter 5: Environment, Health and Quality of Life. European Environment Agency.

[34] Hosseini, H.M. and Kaneko, S. (2012) Causality between Pillars of Sustainable Development: Global Stylized Facts or Regional Phenomena? Ecological Indicators, 14, 197-201. https://doi.org/10.1016/j.ecolind.2011.07.005

[35] Shakya, M. (2009) Competitiveness Assessment of Tourism in Sierra Leone: A Cluster-Based Approach. The World Bank Poverty Reduction and Economic Management Network-International Trade Department.

[36] VSL (2017) VSL Travel. Visit Sierra Leone. https://www.visitsierraleone.org/

[37] Public Sector Reform Unit (2010) Management and Functional Review of the Ministry of Tourism and Cultural Affairs. Government of Sierra Leone, Office of the President, Freetown.

[38] SSL (2012) Tourism Statistics Bulletin 2011. Statistics Sierra Leone, Freetown.

[39] Quast, S. (2011) Regulation of Wetlands: Sections 402 \& 404. In: Ryan, M.A., Ed., The Clean Water Act Handbook, 3rd Edition, American Bar Association, Chicago, 113-136.

[40] Christman, B. (2013) A Brief History of Environmental Law in the UK. Environmental Scientist, 4-8.

[41] Nines, N.W. (2013) History of the 1972 Clean Water Act: The Story behind How the 1972 Act Became the Capstone on a Decade of Extraordinary Environmental Reform. George Washington Journal of Energy \& Environmental Law, 80, 80-106.

[42] Cohen, M.L. (1989) The Common Law in the American Legal System: The Challenge of Conceptual Research. Law Library Journal, 81, 13-32.

[43] Kutler, S.I. and Gale Group (2003) Dictionary of American History: Epidemics and Public Health. 3rd Edition, Charles Scribner's Sons, New York.

[44] Murchison, K.M. (2005) Learning from More than Five-and-a-Half Decades of Federal Water Pollution Control Legislation: Twenty Lessons for the Future. Boston College Environmental Affairs Law Review, 32, 527-598.

[45] Polk, A.A. (2013) The Clean Water Act and Evolving Due Process: The Emergence of Contemporary Enforcement Procedures. Oklahoma Law Review, 65, 717-766.

[46] US FWS (1948) Federal Water Pollution Control Act (Clean Water Act). US Fish and Wildlife Service.

[47] Adler, R.W. (2013) Water and Wastewater Infrastructure in the United States: The Clean Water-Energy-Climate Nexus. George Washington Journal of Energy \& Environmental Law, 4, 1-21.

[48] GPO (1965) Water Quality Act. Government Publishing Office (US).

[49] GPO (1966) Clean Water Restoration Act. Government Publishing Office (US).

[50] GPO (1970) Title I-Water Quality Improvement. Government Publishing Office (US).

[51] Peters, G. and Wooley, J.T. (1972) Richard Nixon: Veto of the Federal Water Pollution Control Act Amendments of 1972. The American Presidency Project.

[52] Downing, D.M. (2011) Scope of "The Watres of the United States" Protected by the Clean Water Act. In: Ryan, M.A., Ed., The Clean Water Act Handbook, 3rd Edition, American Bar Association, Chicago, 11-25.

[53] Witte, E.B. and Minkel-Dumit, N. (2011) Nonpoint Source Pollution Control. In: 
Ryan, M., Ed., The Clean Water Act Handbook, 3rd Edition, American Bar Association, Chicago, 193-206.

[54] McGaffey, K.M. and Moser, K.F. (2011) Water Pollution Control under the National Pollutant Discharge Elimination System. In: Ryan, M., Ed., The Clean Water Act Handbook, 3rd Edition, American Bar Association, Chicago, 27-57.

[55] Sheppard, K. (2012) 8 Environmental Rules That Were Too Controversial to Enact Pre-Election. Mother Jones, 14 November 2012.

[56] Robinson, B. (2011) Victorian Medicine-From Fluke to Theory. British Broadcasting Corporation, 17 February 2011. http://www.bbc.co.uk/history/british/victorians/victorian_medicine_01.shtml

[57] Johnstone, D. and Horan, N. (1996) Institutional Developments, Standards and River Quality: A UK History and Some Lessons for Industrialising Countries. Water Science and Technology, 33, 211-222. https://doi.org/10.2166/wst.1996.0072

[58] Bergman, B.P. (2013) Commentary: Edmund Alexander Parkes, John Snow and the Miasma Controversy. International Journal of Epidemiology, 42, 1562-1565. https://doi.org/10.1093/ije/dyt212

[59] Johnson, S. (2007) The Ghost Map: The Story of London's Most Terrifying Epidemic and How It Changed Science, Cities, and the Modern World, Riverhead Books.

[60] PMC (1892) Cholera and Typhoid Material in the Thames. British Medical Journal, 2, 643-644. https://doi.org/10.1136/bmj.2.1655.643

[61] Alexander, G. (1876) The Rivers Pollution Prevention Act, 1876, 39 \& 40 Vict. C. 75: With Introduction, Notes, and Index. Knight \& Co., London.

[62] Morris, G. and Saunders, P. (2017) The Environment in Health and Well-Being. Oxford Research Encyclopedia of Environmental, Oxford. https://doi.org/10.1093/acrefore/9780199389414.013.101

[63] Enderlein, U.S., Enderlein, R.E. and Williams, W.P. (1997) Water Quality Requirements. In: Helmer, R. and Hespanhol, I., Eds., Water Pollution Control- $A$ Guide to the Use of Water Quality Management Principles, E. \& F. Spon, London, 23-52.

[64] Everything Legal Ltd. (2017) The UK’s Legal Information Website. https://www.lawontheweb.co.uk/

[65] Scalia, A. (1995) Common-Law Courts in a Civil-Law System: The Role of United States Federal Courts in Interpreting the Constitution and Laws. Princeton University, Princeton.

[66] UNICEF (2013) Statistics at a Glance: Sierra Leone.

[67] Bellows, J. and Miguel, E. (2006) War and Institutions: New Evidence from Sierra Leone. The American Economic Review, 96, 394-399. https://doi.org/10.1257/000282806777212323

[68] Rachlinski, J.J. (2006) Bottom-Up versus Top-Down Lawmaking. Cornell Law Faculty Publications 918.

[69] Rapanos, et al. (2005) United States-Certiorari to the United States Court of Appeals for the Sixth Circuit.

[70] Madoux-Humery, A.-S., Dorner, S., Sauvé, S., Aboulfadl, K., Galarneau, M., Servais, P. and Prévost, M. (2016) The Effects of Combined Sewer Overflow Events on Riverine Sources of Drinking Water. Water Research, 91, 218-227. https://doi.org/10.1016/j.watres.2015.12.033 